Published in final edited form as:

Wiley Interdiscip Rev Nanomed Nanobiotechnol. 2012 ; 4(1): 82-95. doi:10.1002/wnan.154.

\title{
Nanotechnology in interventional cardiology
}

\author{
Tillmann Cyrus, Samuel A Wickline, and Gregory M Lanza \\ Washington University in Saint Louis
}

Tillmann Cyrus: cyrust@health.missouri.edu; Samuel A Wickline: saw@wuphys.wustl.edu; Gregory M Lanza: greg.lanza@mac.com

\begin{abstract}
High-grade atherosclerotic stenoses are reduced to zero or minimal residual stenosis grades by a single or a series of balloon angioplasties. Currently, stents are implanted to prevent immediate vascular recoil and elution of an anti-mitotic drug from the stent struts minimizes restenosis. An unwanted side-effect of this drug-elution is delayed re-endothelialization which requires the treatment with two anti-platelet drugs in many cases for a minimum of one year to prevent acute in-stent thrombosis. Advances in stent-design and drug-elution technology, now in its fourth generation, have not abated this issue. Nanotechnology-based local drug delivery has the potential to achieve restenosis prevention while not impeding endothelial healing. Molecularly targeted drugs can be aimed to specifically bind to epitopes in the injured media and adventitia. Thus, endothelial healing may progress unhindered. To prevent restenosis, this technology may be used with bare metal or biodegradable stents. In this article novel nanoparticulate agents will be compared regarding their potential to deliver drugs to molecular targets within the vascular wall. Potential molecular targets, targeting mechanisms, drug-delivery propensities, and biocompatibility will be reviewed.
\end{abstract}

\section{Keywords}

Atherosclerosis; Nanotechnology; Drug delivery; Imaging; Restenosis

The restenosis response after cardiovascular angioplasty and stent implantation is influenced by the mechanical injury during angioplasty ${ }^{1}$, inflammatory responses ${ }^{2}$, and endothelial healing ${ }^{3}$. Hence, prevention of vascular thrombosis and restenosis are paramount factors determining the long-term success of cardiovascular stent implantation. Thrombosis and restenosis appear to be distinct pathologies with the former caused by endothelial injury and the restenosis response triggered by the acute over-stretch injury to the media and adventitia. However, a prolonged endothelial healing period as well as ongoing endothelial dysfunction may also extend the restenosis response emphasizing the benefit of early reendothelialization.

Current drug eluting stents minimize the restenosis response at the expense of prolonged endothelial healing. As a consequence, in-stent thrombosis needs to be prevented with the use of dual anti-platelet agents for a minimum duration of one year. Nevertheless, acute stent thrombosis has been described up to and exceeding 4 years after stent placement ${ }^{4-6}$. Thus, treatment with dual platelet agents is often recommended for periods far in excess of one year. While this is the currently best treatment option and thus standard of care, it leaves several areas of potential improvement. (1) Urgent surgeries typically require the cessation of dual anti-platelet agents putting the patient at risk for acute stent thrombosis and thus pose challenging clinical management issues. (2) Patients that are known to require surgeries within a few months of stent placement often do receive bare metal stents and thus do not get the benefit of local drug treatment. (3) Early and late coronary stent thrombosis occurs in 
a small, yet significant number of patients up to at least 3 years following implantation of drug eluting stents ${ }^{7}$. (4) Small vessels or extremely tortuous vessels may preclude the use of stents altogether and drug-covered angioplasty balloons have so far mostly yielded unsatisfactory restenosis results. (5) While drug eluting stents have significantly decreased the need for revascularization, restenosis still does occur. Finally, another more principal question may be entertained: Since the atherosclerotic stenosis can be treated in a single interventional procedure, should the ideal treatment modality not also allow minimizing the duration of pharmacological follow up treatments?

In conclusion, an ideal drug/agent used to prevent restenosis after angioplasty should be antiproliferative, anti-migratory, anti-inflammatory, and pro-healing. Thus, it should specifically inhibit the restenosis response, i.e. largely inhibit SMC replication. Its duration of action should not unnecessarily exceed the time of restenosis "trigger". Furthermore, it should be non-toxic to the adventitia and endothelium, i.e. not delay endothelial healing and return of endothelial function. Lastly, it should not have systemic effects.

\section{Local non-targeted drug-delivery during interventional procedures}

Systemic drug delivery has shown some success in decreasing restenosis following balloon angioplasty and coronary stent implantation ${ }^{8,9}$. However, in most cases systemic delivery is inefficient ${ }^{10}$ and largely produces side effects ${ }^{11,12}$. The failure of systemic pharmacotherapy is due to inadequate local tissue concentration at systemic doses of the respective biological agent that can be safely given to the patient. These considerations provide a rationale for local drug delivery.

\section{Local drug infusion}

Initially, porous balloons and microporous balloons were evaluated for this task. With these devices drugs ${ }^{13}$, antisense oligodeoxynuleotides ${ }^{14}$, adenoviral vectors ${ }^{15}$ and even nanoparticulate agents ${ }^{16,17}$ have been successfully delivered in animal models. The efficiency of porous balloon drug delivery varies substantially between different devices ${ }^{18}$, agents delivered ${ }^{19}$ and in case of nanoparticles the size of these particles ${ }^{20}$. A drawback is the observation that high delivery pressures and large volumes of perfused solutions may cause significant vascular damage and thereby may increase intimal thickening ${ }^{17}$. Concerns regarding vascular barotrauma are related to balloon type, infusion pressures, agents used, and type and condition of the vessel treated ${ }^{21,22}$. In addition, non-homogenous local as well as unavoidable systemic delivery, remain issues. All these parameters need to be evaluated for any new compound tested, which makes this technology cumbersome. Nevertheless, the local delivery of an antisense phosphorodiamidate morpholino oligomer (AVI-4126) has been successful in a small group of patients with coronary artery disease using the Infiltrator catheter ${ }^{23}$. While the compound was shown to decrease restenosis in human coronary arteries, the balloon catheter could not be advanced into the lesion in 8 out 44 patients and 6 coronary artery dissections occurred in the 25 patients in whom the balloon was inflated. These data highlight the technical challenges of this delivery technology. Due to such difficulties and the above mentioned concerns, these devices have not gained widespread clinical application. Another rationale to utilize targeted agents is given from the fact that even when local delivery of non-targeted agents through a porous balloon is optimized, the majority of the compounds are delivered to the vasa vasorum and periadventitial microvasculature with substantially lesser delivery to the media and intima ${ }^{24,25}$.

Compared to porous balloons, drug-coated balloons and double-balloons are less traumatic to the arterial wall. They offer the advantage of homogenous drug transfer into the vessel wall either during a low-pressure inflation of the drug-coated balloon or during an extended incubation time between two balloons that entrap the drug in the arterial segment of interest. 


\section{Local drug delivery with drug-coated balloons}

Drug-coated balloons have undergone intensive investigation including evaluation in clinical trials. Paclitaxel-coated balloon (PCB) catheters have significantly decreased in-segment late luminal loss and restenosis at 6 months in a trial that enrolled 52 patients with in-stent restenosis ${ }^{26}$. At 12 months, the rate of major adverse cardiac events was $4 \%$ in the coated balloon group vs. $31 \%$ in the uncoated balloon group $(\mathrm{P}=0.01)$. In the Paclitaxel-Eluting PTCA-Balloon Catheter in Coronary Artery Disease-2 In-Stent Restenosis (PEPCAD-2 ISR) trial treatment of in-stent restenosis using a balloon coated with paclitaxel was shown to be as good as or better than Taxus paclitaxel-eluting stents at treating in-stent restenosis ${ }^{27}$. In the PEPCAD-3 trial, the paclitaxel-coated-balloon/stent system was compared against the sirolimus-eluting Cypher stent in 637 patients with de-novo coronary artery stenoses (Hamm CW. AHA Scientific Sessions 2009: Nov. 14, 2009). Here it did not meet non-inferiority criteria and its associated target-lesion and target-vessel-revascularization rates were double those reported with Cypher stenting. Another trial with this paclitaxel-coated balloon system was terminated prematurely when the PCB group showed higher per cent diameter stenosis (43.6\% vs. $24.3 \%, \mathrm{p}=0.029$ ), angiographic restenosis ( 32.1 vs. $10.3 \%, \mathrm{p}=0.043$ ) and MACE ( $35.7 \%$ vs. $13.8 \%, \mathrm{p}=0.054)$ when compared to Taxus DES after PCI of small coronary arteries $^{28}$. Overall, the results of drug-coated balloon trials are mixed, but encouraging nevertheless to continue further investigation.

\section{Local drug delivery with double-balloon catheters}

In an early study, local delivery of paclitaxel using a double-balloon perfusion catheter and bare metal stent implantation failed to show any difference compared to placebo in response to balloon-injury in porcine coronary arteries ${ }^{29}$. However, in a more recent study including some investigators of the aforementioned study, locally-delivered paclitaxel showed marked reduction of neointimal proliferation and complete endothelialization 42 days after treatment in a porcine mode ${ }^{30}$. Compared to the earlier study, the amount of drug infused was similar, but a new double-balloon device and higher instillation pressures were used. Also, dual antiplatelet medication was given daily. Another compound that had been shown to inhibit vascular smooth muscle cell (VSMC) growth in vitro, the glucose analog 2-Deoxy-Dglucose (2-DG), has been evaluated in the prevention of restenosis using a double-balloon approach in a porcine coronary artery model ${ }^{31} .42$ days after balloon overstretch-injury and local infusion through the Genie catheter, arteries exposed to this compound showed similar degrees of neointimal thickness, area stenosis, and re-endothelialization as those treated with rapamycin-eluting stents.

Limitations of the double-balloon catheter technology are the potential for local barotrauma to the vessel caused by the two balloons, regulation of the infusion pressure, and duration of incubation times. Modifications to the catheters have allowed blood to stream through a central channel in the catheter and thus prevent ischemia in the distal vessel. Nevertheless, ischemia in the occluded segment of the vessel and trauma within the two balloon-occluded segments will occur and increase with the duration of incubation. Especially with nontargeted infusates, occlusion times to enable sufficient drug delivery may reach $30 \mathrm{~min}^{32}$. These considerations provide a strong argument for the use of targeted infusates, which may decrease the incubation times to less than 2 minutes. Another limitation of the doubleballoon delivery technology that may at least be partially overcome by molecularly-targeted drug-delivery is the loss of infusate through side branches. In this scenario, molecularlytargeted nanoparticles may still allow for adequate drug delivery, while non-targeted agents may run off too quickly to allow for significant retention times at the targeted tissue. 


\section{Drug eluting stents (DES)}

The concept of using stents as a reservoir for drugs is appealing due to reliability of drug delivery and predictable release kinetics. Indeed, in today's clinical practice most patients receive local-drug delivery through drug-eluting stents. Important parameters that are of interest for drug delivery through stents pertain to 1) drug type,2) drug release kinetics and physiological transport forces, 3) mechanical issues such as stent strut apposition and deployment forces, and 4) oral antiplatelet regimen post DES implantation. All these parameters exert effects on restenosis and endothelial healing. An extensive literature review regarding the differences in the restenosis suppression for currently FDA approved DES has been recently published ${ }^{33}$. Of interest here is the observation that at least in some cases higher rates of restenosis suppression may be paralleled by prolonged endothelial dysfunction ${ }^{34,35}$. This may be related to particular drugs, but it may also be simply related to concentration gradients. Stent-based delivery of drugs leads to large concentration gradients over a few micrometers from the stent struts ${ }^{36}$. In order to achieve therapeutic drug effects in the media, the immediate subendothelial layer is exposed to relatively high drug dosages, which delays endothelial healing. In general, hydrophobic drugs achieve higher mean concentrations closer to the intima when compared to hydrophilic drugs and both are affected by inhomogeneous strut placement ${ }^{36}$. If stent struts are not apposed well, the restenosis response may not be inhibited and similarly to bare metal stents (BMS), the struts can become a nidus for thrombus formation. To avoid such stent strut mal-apposition, DES and BMS are often deployed at much higher pressures when compared to plain balloon angioplasty which is aimed at stenosis reduction. While this solves the anatomical problem, a sometimes neglected fact is that restenosis severity correlates with stretch-injury severity, at least in the porcine model ${ }^{1}$. Thus, lower drug levels might achieve similar restenosis suppression, if they can be delivered with less vascular injury. This observation provides another rationale for further research into nanotechnology-based drug delivery, which might be successful without stent placement. After DES implantation, stent-thrombosis needs to be prevented with long-term dual antiplatelet therapy. Apart from clinical situations such as trauma or emergent surgeries, when some or all such therapy needs to be temporarily withdrawn, a small but significant number of patients fail to continue adhering to dual antiplatelet therapy for various reasons. These appear to be the scenarios where most of the stent thrombosis events occur ${ }^{37,38}$. Overall, the number of patients not receiving or taking dual-antiplatelet therapy according to guidelines is significant and has been reported to occur in up to $22-29 \%$ of patients in the "real-world" experience outside clinical trials 39,40 . This has led to the issuance of specific guidelines ${ }^{41}$. Importantly, very late stent thrombosis (> 1year) has been reported to at least 4.5 years with DES and up to 11 years with BMS, with very late stent thrombosis and reinfarction being more frequent with $\mathrm{DES}^{4}$. Again, these concerns provide a rationale for further research of nanotechnology-based delivery options that may achieve adequate restenosis suppression without requiring long-term dual antiplatelet therapy.

While the initial successes of DES were measured with the suppression of restenosis, endothelial healing is receiving increasing attention. As mentioned above, there often is a dichotomy between restenosis suppression and endothelial healing. In some cases the impact on endothelial healing may be so severe that a drug-eluting stent has to be withdrawn from clinical testing despite excellent results in restenosis prevention ${ }^{42}$. Since delayed endothelial healing is more pronounced in DES than BMS and plain angioplasty, intense research efforts are taking place to improve on this. Different drugs for delivery are being tested, modifications to polymers are being made, and even polymer-free drug-carrying stents are being tested. Polymer coatings were used early on to facilitate drug-adhesion to the stent and controlled release from the stent. The ideal polymer should be biological inert. Indeed some animal studies suggested that phosphorylcholine-coating (PC) of stents may have good 
biocompatibility ${ }^{43}, 44$. Yet, others showed extensive inflammatory responses and fibrocellular proliferation in response to stents coated with different polymers. As an example, in a study in porcine coronary arteries four weeks after implantation of polymerloaded stents, the thickness of tissue response was $0.79 \pm 0.22,1.12 \pm 0.01,2.36 \pm 0.60$, $1.24 \pm 0.36$, and $1.43 \pm 0.15 \mathrm{~mm}$, for the biodegradable polycaprolactone (PCL), polyhydroxybutyrate valerate (PHBV), and polyorthoester (POE) and the non-biodegradable polyurethane (PUR) and silicone (SIL). Less, but still severe responses were observed for the biodegradable polyglycolic/polylactic acid (PGLA) and polyethylene oxide/polybutylene terephthalate (PEO/PBTP) $(0.46 \pm 0.18$ and $0.61 \pm 0.23 \mathrm{~mm}$, respectively) and for the nonbiodegradable polyethylene terephthalate (PETP) $(0.46 \pm 0.11 \mathrm{~mm})$ coated stents $^{45}$. More novel polymers as well as antiproliferative agents and polymer-free drug-eluting stents are undergoing clinical evaluation and have been recently reviewed by S. Garg and P. Serruys ${ }^{46}$. Exemplifying a rationale for further research into polymer-free drug delivery, polymer-free sirolimus stents compared to polymer coated sirolimus (Cypher®) stents have been recently shown to improve endothelial healing in an iliac artery injury model in New Zealand White rabbits ${ }^{47}$. However, the suppression of neointimal thickening was less robust. Furthermore, significant differences in the rate of endothelialization of DES in current clinical use have been demonstrated in animal models ${ }^{48}$. The question remains, if sacrificing some restenosis suppression effects in favour of improved endothelial healing will be clinically more important. Furthermore, could a technology such as molecularly targeted delivery achieve both, improved endothelial healing and reduced restenosis?

Likely more important than endothelial healing as assessed by microscopy ex vivo or optical coherence tomography in vivo may be the endothelial function. While initially not completely understood, endothelial function does not necessarily coincide with endothelial healing.

Endothelial dysfunction has been demonstrated for sirolimus-eluting stents but not for BMS for periods up to 6 months $\mathrm{s}^{34,35}$. The clinical significance of these findings remains uncertain. However, it is known that endothelial dysfunction contributes to atherogenesis and is independently associated with future cardiovascular events ${ }^{49-51}$. Thus, avoiding endothelial dysfunction after percutaneous coronary intervention (PCI) may be at least of hypothetical benefit.

In conclusion, areas of improvements with DES technology which also open avenues for alternate modalities such as molecularly targeted nanotechnology are improvements in endothelial healing, including early return of endothelial function and prevention of stentthrombosis. Ideally, this should be accomplished while decreasing duration of dualantiplatelet therapy. In addition, molecularly-targeted drug-delivery may be tested for delivery to anatomical locations that evade deliverability of stents, or in case of restenosis in vascular segments that already have two or more layers of stents.

\section{Nanoparticle-facilitated drug-delivery during interventional procedures Rationale for molecularly-targeted delivery}

Despite two decades of optimization of mechanical delivery systems and strategies, delivery efficiency as well as retention of the respective agent at the target site, remain issues. Many agents may have failed to show beneficial effects simply because they were washed out or could not penetrate into the target site despite long incubation periods. Nanotechnology may help specifically target such previously "failed" drugs to the epitopes of interest and elicit the desired effects. The prevention of vascular complications may be a unique feature of nanotechnology in interventional cardiology. Detection of dysfunctional endothelium may be possible with nanoprobes targeted to molecular markers that are expressed on activated 
endothelium. In addition to detection, such nanoprobes may simultaneously deliver agents to interrupt the activation process and prevent atherosclerotic lesion growth.

\section{Prevention of restenosis}

In addition to the drugs that are already in clinical use on drug-eluting stents, many more agents of interest have been evaluated with various results. For instance, some studies showed promising results with respect to diminishing restenosis in animal studies, but then failed to significantly reduce restenosis in humans. These include drug eluting stents with dexamethasone ${ }^{52}$, heparin ${ }^{53}$, glycoprotein IIb/IIIa antibodies ${ }^{54}$, and actinomycin ${ }^{55}$.

In contrast, sirolimus showed promising short-term (28-30 days) results for the prevention of restenosis in porcine models ${ }^{56-58}$, but failed to show a statistically significant difference compared to bare-metal stents 90 and 180 after implant ${ }^{58}$. Nevertheless, clinical trials in humans have shown excellent long-term results for sirolimus-coated stents ${ }^{59,60}$. These data highlight the fact that animal studies are not necessarily translatable to the human condition. In case of the "failed" drugs, it is important to remember that these drugs were not chosen randomly but due to proven efficacy for instance in the inhibition of VSMC in in vitro models. Thus, the lack of efficacy in animal studies and/or human trials may not necessarily be the result of "failure" of the drug, but may be due to lack of sufficient delivery and/or retention at the target site. Here, novel nanotechnology-based delivery methods may open new avenues to test the efficacy of some of the drugs that did not show satisfactory restenosis prevention with conventional delivery methods.

Delayed endothelial healing ${ }^{61}$ and endothelial dysfunction ${ }^{34}$ are additional concerns after implantation of drug-eluting stents. In the quest to find agents that may inhibit in-stent restenosis while also improving endothelial function, potential drugs as well as local gene transfers have shown promising results. Among the drug-candidates is angiotensin-(1-7). This is an endogenous, biologically active peptide of the renin-angiotensin system. It has vasodilatory, antithrombotic, and antiproliferative properties and has been shown to inhibit stent-induced neointima formation in male Wistar rat aortas ${ }^{62}$. Interestingly, angiotensin-(17) also attenuated stenting-induced impairment of endothelium-dependent relaxation to phenylephrine. Among the gene-candidates are human vascular endothelial growth factor (VEGF) gene eluting stents. Upon deployment of these stents into iliac arteries of hypercholesterolemic rabbits, restenosis was diminished at 3 three months and reendothelialization was nearly complete after 10 days ${ }^{63}$.

\section{Targets for nanoparticle-facilitated drug-delivery}

\section{Non-specific}

So called "bioadhesive" nanoparticles have been generated by applying carbopol 940 as stabilizer and bioadhesive agent to poly (lactide-co-glycolide) PLGA nanoparticles ${ }^{64}$. These particles are spherical and measure 157-248 depending on the concentration of carbopol. The rapamycin, a highly hydrophobic drug, is entrapped during the formation process of these nanoparticles. In an ex vivo perfusion model using dog carotid arteries, the investigators showed that retention and uptake efficiency on the arterial wall increased with increasing concentrations of carbopol $940^{64}$. While the "bioadhesive" approach is intriguing, it does not entail targeting to any specific epitopes, but that the particles will stick to any tissue they get in contact with. Thus, local delivery will be paramount. Another potential pitfall of this approach is the bioadhesive agent used. Carbopol 940 is a cross-linked polyacrylate polymer that is used in gels for skin and hair applications. It is hygroscopic and provides high viscosity. The toxicological properties of this material have not been clearly defined for intra-corporal use. 
One novel strategy to enhance local drug delivery is to utilize magnetically induced release of a drug-payload of a nanoparticle. Here, the nanoparticles are not targeted to specific epitopes in the tissue, but magnetically attracted to the metallic stents using uniform fieldinduced magnetization. Recently, magnetic nanoparticles (MNPs) designed for efficient entrapment and delivery of paclitaxel have been shown to inhibit VSMC in vitro and to achieve higher localization rates of locally delivered MNPs to stented arteries in rats under magnetic conditions ${ }^{65}$. Both, VSMC growth in vitro and in-stent restenosis in vivo were inhibited. Advantages of this technology may be the ability to individualize drug dosing, and repeat delivery to the target site. A disadvantage in the use of magnetic fields may be given for patients with metallic implants unless lower field strengths than used in this study, may prove efficient.

\section{Endothelium}

Intercellular cell-adhesion molecule-1 (ICAM-1) is constitutively expressed on the luminal surface of endothelial cells ${ }^{66}$ and up-regulated in vascular inflammation ${ }^{67}, 68$. Furthermore, blocking of ICAM-1 with antibodies has been shown to diminish leukocyte adhesion to endothelial cells ${ }^{69}$, and antibody-ICAM-1 conjugates have been shown to become internalized into cells ${ }^{70}$. Thus, ICAM is an attractive target not only for imaging but also therapeutic nanoparticle-based strategies. Indeed, catalase nanoparticles targeted to ICAM-1 have been shown to be internalized into and protect endothelial cells from oxidative stress in human umbilical endothelial cells ${ }^{71,72}$. More recently, a nanoparticle-peptide conjugate has been created by covalently linking PEGylated PLGA nanoparticles to the cLABL peptide ${ }^{73}$. These nanoparticles demonstrated rapid binding to HUVEC with up-regulated ICAM-1 and they were quickly endocytosed and trafficked to lysosomes ${ }^{73}$. In an early step to develop an ICAM-1 targeted nanoparticulate agent for CT imaging of atherosclerotic plaque, antiICAM-1 antibodies have been covalently bound to liposomes containing iohexol and were shown to bind to the surface of activated human coronary artery endothelial cells in vitro with high specificity as determined with ELISA and shown in immunohistochemistry ${ }^{74}$.

Vascular adhesion molecule-1 (VCAM-1) is another endothelial cell adhesion molecule that has been targeted for nanoparticle-based imaging. In these experiments, a phage displayderived VCAM-1-targeting peptide was attached to monocrystalline magnetic nanoparticles (VINP-28) with a diameter of $38 \mathrm{~nm}$ and injected into $\mathrm{apoE}^{-/-}$mice $^{75}$. MRI and optical imaging showed colocalization of the VINP-28 with endothelial cells and atheromata of atorvastatin-treated apoE $^{-/}$mice showed reduced VINP-28 deposition and VCAM-1 expression. Nanocarriers have also been targeted to platelet-endothelial cell adhesion molecule (PECAM-1). Interestingly, differences in the intracellular trafficking were observed with mAb62-nanocarriers trafficking to lysosomes, whereas mAb32-nanocarriers had prolonged residence in pre-lysosomal vesicles ${ }^{76}$. These experiments enforce the concept that nanoparticles can be designed to preferentially target specific intra-cellular localizations.

Another group of investigators generated nanoparticles targeted to E- and P-selectin by covalently binding a ligand of E- and P-selectin to poly-L,D-lactic acid polymer (PLA) nanoparticles and showed adhesion of these nanoparticles to HUVEC in vitro ${ }^{77}$.

A different type of nanoparticles, PAMAM dendrimers, has also been successfully targeted to E-and P-selectin by attaching anti E/P-selectin antibodies onto the PAMAM dendrimers ${ }^{78}$. These nanoparticles increased gene delivery to endothelial cells expressing Eselectin in human saphenous vein segments ex vivo.

Very intriguing experiments have expanded on the antibody-facilitated ICAM-1 targeting additional evaluation of not only different antibody concentrations per particle but various 
physical shapes on the efficacy of nanoparticle delivery. Interestingly, nanoparticle carrier geometry significantly influenced not only endothelial drug targeting, but also intracellular trafficking and effects. In these experiments, ICAM-1 targeted disk-shaped nanoparticles had longer systemic half-lives and more targeting specificity, while nanoparticle spheres were endocytosed much more rapidly ${ }^{79}$ In additional experiments, it was shown that various nanoparticle-antibody densities and carrier concentrations lead to similar saturations of activated endothelial cells but not quiescent cells ${ }^{80}$.

In the quest to discover novel peptide ligands that bind to proteins expressed on endothelial cells, in vivo phage display screenings in humans have identified a large collection of unique targets ${ }^{81}$. While the use of in vivo phage display to identify peptides interacting differently with protein targets in vascular beds of organs or tissues was first reported 15 years ago ${ }^{82}$, novel technologies including bacteria-free phage display, and real-time PCR have allowed the creation of large libraries of ligand-targeted phage displays that may be used not only for peptide therapy but also gene therapy ${ }^{83}$. Proteomics presents an alternative way to identify membrane proteins. A novel three-dimensional separation method which outperforms the current two-dimensional methods by significantly enhancing protein identifications has recently been published ${ }^{84}$. Using endothelial cell membranes from lung tissue, more than 500 lipid-embedded proteins were identified with this new method. Like the newer phage display methods, this novel proteomics method is likely to facilitate detection of a multitude of heretofore unknown membrane-embedded ligands for nanoparticle-based targeting.

Another interesting approach to prevent injury-mediated endothelial cell activation is the genetic modification of endothelial cells through magnetic nanoparticle-mediated transfection with therapeutic genes. Initially, viral vectors were attached to superparamagnetic nanoparticles and an external magnetic field applied to enhance the target-specific localization of the nanoparticles. With this methodology, enhanced transfection could be demonstrated in vitro and in vivo ${ }^{85}$, 86 . Using thermally cross-linked superparamagnetic iron oxide nanoparticles covalently conjugated with polyethylenimine linked with plasmid DNA, increased cellular uptake was shown in the presence of an external magnetic field and the expression of PAI- 1 was inhibited ${ }^{87}$. In order to increase resistance of endothelial cells to oxidative damage, catalase has been delivered successfully using magnetically guided delivery with magnetically responsive nanoparticles ${ }^{88}$. In these experiments, the nanoparticles were formed by precipitation of calcium oleate in the presence of magnetite-based ferrofluid (controlled aggregation/precipitation) and filled with catalase and superoxide dismutase. In a magnetic field, these nanoparticles were rapidly taken up by cultured endothelial cells and provided increased resistance to oxidative stress $^{88}$.

\section{Media - HDL / macrophages}

High-density lipoproteins (HDL) naturally penetrate the endothelium because of their small size and play a pivotal role in the reverse cholesterol transport from lipid-rich atherosclerotic lesions. Since the HDL particles are naturally biocompatible and can be modified to carry imaging-payloads, they have been investigated as an attractive nanoparticulate carrier to image vulnerable atherosclerotic plaque. In earlier experiments, a reconstituted HDL (rHDL)-like particle was incorporated with a gadolinium-chelate and shown to facilitate imaging of atherosclerosis in the abdominal aorta of $\mathrm{apoE}^{-/-}$mice by MRI following tail vein injection ${ }^{89}$. These experiments, which were carried out with spherical HDL particles, were later extended using disk-shaped rHDL-like particles prepared either with a sonication process to form the particles or cholate dialysis with phospholipids conjugated with GdDTPA $^{90}$. As in the previous experiments, these particles accumulated in the atherosclerotic abdominal aorta with the highest signal intensity 24 hours after injection into the tail veins of apo $\mathrm{E}^{-/-}$mice. Similar to detecting differences in the influence of the shape of 
nanoparticles on cellular binding on uptake observed with ICAM-1 targeted particles (as reviewed above ${ }^{79}$ ), the physical particle shape of the various HDL-like particles may also explain some of the differences in efficacy.

Further expanding the armamentarium of macrophage-based media-targeting, , a fullysynthetic HDL/apoA-1 mimicking nanoparticle has been developed and been shown to signal-enhance atherosclerotic apoE ${ }^{-/-}$mouse aortas when imaged with $\mathrm{MRI}^{91}$. To extend HDL particle based imaging of atherosclerosis to imaging modalities such as CT and optical imaging, inorganic nanocrystals either containing gold for CT or quantum dots for optical imaging, have been used to replace the natural HDL core ${ }^{92}$. While HDL- like particles have been useful to detect atherosclerosis in vivo, only a few studies have explored rHDL-like particles for the delivery of drugs to the liver ${ }^{93}$, but not for suppression of atherosclerosis.

Another approach takes advantage of the fact that atheromatous plaque, especially the so called vulnerable plaque, contains a large number of macrophages ${ }^{94}$. To exploit the migration of macrophages into such plaque, crystalline iodinated particles containing an esterified derivative of the $\mathrm{X}$-ray contrast agent diatrizoic acid were dispersed with biocompatible surfactant and intravenously injected into rabbits with atheromatous plaques generated by balloon injury in the abdominal aorta ${ }^{95}$. Enhancement of atherosclerotic plaques was most pronounced two hours after injection of these nanoparticles as imaged with CT. Furthermore, a nanoparticulate agent was developed for detection of macrophages in atherosclerotic plaque using MRI. In these experiments, Gd-DTPA-carrying immunomicelles were linked with a biotinylated monoclonal rat anti-mouse antibody to murine macrophage-scavenger receptor-A types I and II and infused into apoE ${ }^{-/-}$mice $^{96}$. A strong correlation between macrophage content in atherosclerotic plaques as quantified via histology and signal-enhancement in in vivo MRI was observed.

Overall many interesting avenues to interrogate the vascular media for lipid deposition and potential vulnerability of plaque are available. At present, these modalities are useful for research and diagnostic purposes. It appears feasible that nanoparticles aimed at macrophages and lipid accumulation may also be used as drug carriers and thus stabilize vulnerable plaque. Given the inherent time delay to target and incorporate into macrophages and for macrophages to migrate into the lesions, this technology is unlikely to be used during interventional procedures, but it may non-invasively treat lesions, or via detection of vulnerable plaque, initiate interventional procedures.

\section{Media - SMC}

Locally delivering drugs to targets within the media is especially intriguing with regards to preventing restenosis since restenosis is largely driven by VSMC. Activation of VSMC is triggered by the angioplasty and results in increased rates of mitoses and stimulates migration. While drug-eluting stent technology has been successfully delivering drugs to this target with drug-concentration gradients decreasing with the physical distance from the drug-eluting stent, nanotechnology-based molecularly-targeted drugs can be delivered deep into the tissue fissures created by angioplasty and retained locally.

In one recent example, combining stent placement with local magnetically guided delivery of magnetic paclitaxel-containing nanoparticles has resulted in significant retention of this drug in the arterial wall and inhibition of in-stent stenosis in a rat carotid stenting model ${ }^{65}$.

Promising with respect to practicability for local delivery during PCI procedures and successfulness of prevention of vascular restenosis are perfluorocarbon (PFC) nanoparticles which can be molecularly targeted, non-invasively imaged, and reliably function as drugcarriers $^{97}$. These nanoparticles with an average mean diameter of $250 \mathrm{~nm}$, have been 
successfully targeted to $a_{v} \beta_{3}$-integrin exposed in overstretch-injured carotid arteries in pigs using local infusion and epitope-specific binding has been shown with MRI and histology ${ }^{98}$. In these experiments, the nanoparticles carried gadolinium as "imaging-payload", which facilitated non-invasive imaging. In subsequent experiments, these PFC nanoparticles were additionally conjugated with paclitaxel as therapeutic payload and shown to inhibit overstretch-injury-induced restenosis in NZW rabbit femoral arteries (figure 2) ${ }^{99}$. The PFC nanoparticle platform is particularly intriguing because it is very versatile with respect to targeting numerous epitopes, imaging capability with ultrasound, X-ray, MRI, or SPECT depending on the imaging payloads, and drug delivery abilities ${ }^{100}$. Another advantage of the PFC nanoparticles is their biocompatibility.

\section{Blood platelets - thrombus}

Molecular imaging of thrombus is intriguing because 1) information may be obtained noninvasively, 2) without using radioactive tracers, 3) highly sensitive nanoparticle agents may detect very small thrombus in developing stages, and 4) thrombus-specific targeted thrombolytic therapy may be provided without exerting undue systemic effects.

Activated blood platelets on clots express P-selectin. A paramagnetic nanoparticle containing gadolinium diethylene-triamine-pentaacetic acid (Gd-DTPA) was mixed with an anti-human P-selectin lectin-EGF domain monoclonal antibody (PsL-EGFmAb) and incubated with platelet and blood clots respectively in vitro as well as intravenously infused into dogs upon left femoral vein de-endothelialization with a nylon monofilament ${ }^{101}$. T1weighted imaging in a 1.5-T clinical MR imager showed significant contrast enhancement in the platelet and blood clots targeted with these nanoparticles in vitro and in vivo contrast enhancement in the dogs showed higher signal intensities in the injured femoral vein areas than the control. In another model, liposomes were decorated with RGD peptides and targeted to the GpIIb/IIIa integrin, which is up-regulated on activated platelets ${ }^{102}$. These nanoparticles were infused into the left cardiac chamber in a carotid artery restenosis model in rats and subsequently shown to be co-localized with thrombus on the injured endothelium using fluoroscopy and SEM. Alternatively to P-selectin and the GpIIb/IIIa integrin, the $a_{v} \beta_{3}$-integrin has a long track-record for successful nanoparticle-facilitated targeting of thrombus ${ }^{103}$. In initial studies, perfluorocarbon-nanoparticles were targeted to this integrin in a canine thrombosis model and imaged with ultrasound ${ }^{103}$. The same group recently created manganese-based nanoparticles for MR imaging and targeted them against fibrin ${ }^{104}$. In the initial studies these manganese oxide nanocolloids (ManOC) bound to fibrin in vitro and the MR characteristics were established while in vivo studies are currently underway ${ }^{104}$.

\section{Conclusion}

The restenosis response after cardiovascular angioplasty and stent implantation is influenced by the mechanical injury during angioplasty, inflammatory responses, and endothelial healing. Thus an ideal drug/agent used to prevent restenosis after angioplasty should be antiproliferative, anti-migratory, anti-inflammatory, and pro-healing. Drugs fulfilling some or most of these criteria typically cannot achieve meaningful local effects when systemically delivered. Even when locally delivered, non-targeted drugs often do not accumulate in quantities high enough to achieve the desired effects. Drug-eluting stents are standard-ofcare but require long-term oral dual-antiplatelet therapy. An ongoing issue pertaining to restenosis-prevention and endothelial healing in the design of drug- and deliveryformulations for DES is that improvements in achieving of the one goal may be met with a worsening of the other.

Molecularly-targeted nanoparticle-facilitated delivery of drugs to selected epitopes in the angioplasty-injured vascular wall has already been shown to be feasible for several types of 
nanoparticles and in various animal models of vascular injury. Individual cell-types (e.g. macrophages, VSMCs), extracellular components (e.g. collagen), or epitopes occurring on various cell-types (e.g. $a_{v} \beta_{3}$-integrin) can be specifically targeted and thus therapy tailored to the desired effects. Importantly, nanoparticle-facilitated delivery of drugs deep into the media during angioplasty has been shown to result in restenosis prevention while not delaying endothelial healing in animal models. Current research is focussed on optimizing the effects on both restenosis prevention and endothelial healing. It is anticipated that in the near future, some of these nanoparticle-drug formulations will enter clinical trials. In interventional procedures, the molecularly-targeted nanoparticles will be locally infused using double-balloon catheters, between the initial angioplasty and the subsequent stent placement.

\section{References}

1. Schwartz RS, Huber KC, Murphy JG, Edwards WD, Camrud AR, Vlietstra RE, Holmes DR. Restenosis and the proportional neointimal response to coronary artery injury: Results in a porcine model. Journal of the American College of Cardiology. 1992; 19:267-274. [PubMed: 1732351]

2. Kornowski R, Hong MK, Tio FO, Bramwell O, Wu H, Leon MB. In-stent restenosis: Contributions of inflammatory responses and arterial injury to neointimal hyperplasia. Journal of the American College of Cardiology. 1998; 31:224-230. [PubMed: 9426044]

3. Finn AV, Nakazawa G, Joner M, Kolodgie FD, Mont EK, Gold HK, Virmani R. Vascular responses to drug eluting stents: Importance of delayed healing. Arterioscler Thromb Vasc Biol. 2007; 27:1500-1510. [PubMed: 17510464]

4. Brodie B, Pokharel Y, Fleishman N, Bensimhon A, Kissling G, Hansen C, Milks S, Cooper M, McAlhany C, Stuckey T. Very late stent thrombosis after primary percutaneous coronary intervention with bare-metal and drug-eluting stents for st-segment elevation myocardial infarction: A 15-year single-center experience. JACC: Cardiovascular Interventions. 2011; 4:30-38. [PubMed: 21251626]

5. Vink MA, Dirksen MT, Suttorp MJ, Tijssen JGP, van Etten J, Patterson MS, Slagboom T, Kiemeneij F, Laarman GJ. 5-year follow-up after primary percutaneous coronary intervention with a paclitaxel-eluting stent versus a bare-metal stent in acute st-segment elevation myocardial infarction: A follow-up study of the passion (paclitaxel-eluting versus conventional stent in myocardial infarction with st-segment elevation) trial. JACC: Cardiovascular Interventions. 2011; 4:24-29. [PubMed: 21251625]

6. Spaulding C, Teiger E, Commeau P, Varenne O, Bramucci E, Slama M, Beatt K, Tirouvanziam A, Polonski L, Stella PR, Clugston R, Fajadet J, de Boisgelin X, Bode C, Carrié D, Erglis A, Merkely B, Hosten S, Cebrian A, Wang P, Stoll H-P, Henry P. Four-year follow-up of typhoon (trial to assess the use of the cypher sirolimus-eluting coronary stent in acute myocardial infarction treated with balloon angioplasty). JACC: Cardiovascular Interventions. 2011; 4:14-23. [PubMed: 21251624]

7. Daemen J, Wenaweser P, Tsuchida K, Abrecht L, Vaina S, Morger C, Kukreja N, Jüni P, Sianos G, Hellige G, van Domburg RT, Hess OM, Boersma E, Meier B, Windecker S, Serruys PW. Early and late coronary stent thrombosis of sirolimus-eluting and paclitaxel-eluting stents in routine clinical practice: Data from a large two-institutional cohort study. Lancet. 2007; 369:667-678. [PubMed: 17321312]

8. Kunishima T, Musha H, Eto F, Iwasaki T, Nagashima J, Masui Y, So T, Nakamura T, Oohama N, Murayama M. A randomized trial of aspirin versus cilostazol therapy after successful coronary stent implantation. Clinical Therapeutics. 1997; 19:1058-1066. [PubMed: 9385493]

9. Tamhane U, Meier P, Chetcuti S, Chen KY, Rha S-W, Grossmann MP, Gurm H. Efficacy of cilostazol in reducing restenosis in patients undergoing contemporary stent based pci: A metaanalysis of randomized controlled trials. EuroIntervention. 2009; 5:384-393. [PubMed: 19736165]

10. Ikeoka D, Vieira C, Lemos P, Strabelli T, da Silva E, Perin M, Groselj-Strele A, Tiran B, Tiran A, Caramelli B. Azithromycin does not prevent six-month myointimal proliferation but attenuates the transient systemic inflammation occurring after coronary stenting. Clinical Research in Cardiology. 2009; 98:44-51. [PubMed: 18853090] 
11. Lefkovits J, Topol EJ. Pharmacological approaches for the prevention of restenosis after percutaneous coronary intervention. Progress in Cardiovascular Diseases. 1997; 40:141-158. [PubMed: 9327830]

12. Landzberg BR, Frishman WH, Lerrick K. Pathophysiology and pharmacological approaches for prevention of coronary artery restenosis following coronary artery balloon angioplasty and related procedures. Progress in Cardiovascular Diseases. 1997; 39:361-398. [PubMed: 9050821]

13. Oberhoff M, Kunert W, Herdeg C, Küttner A, Kranzhöfer A, Horch B, Baumbach A, Karsch KR. Inhibition of smooth muscle cell proliferation after local drug delivery of the antimitotic drug paclitaxel using a porous balloon catheter. Basic Research in Cardiology. 2001; 96:275-282. [PubMed: 11403421]

14. Gunn J, Holt CM, Francis SE, Shepherd L, Grohmann M, Newman CMH, Crossman DC, Cumberland DC. The effect of oligonucleotides to c-myb on vascular smooth muscle cell proliferation and neointima formation after porcine coronary angioplasty. Circ Res. 1997; 80:520531. [PubMed: 9118483]

15. Luo Z, Palasis M, Yamakawa M, Liu LX, Vincent KA, Trudell L, Akita GA, Koch WJ, Cheng SH, Gregory RJ, Jiang C. Catheter-mediated delivery of adenoviral vectors expressing $\beta$-adrenergic receptor kinase c-terminus inhibits intimal hyperplasia and luminal stenosis in rabbit iliac arteries. The Journal of Gene Medicine. 2004; 6:1061-1068. [PubMed: 15386742]

16. Chapman G, Lim C, Gammon R, Culp S, Desper J, Bauman R, Swain J, Stack R. Gene transfer into coronary arteries of intact animals with a percutaneous balloon catheter. Circ Res. 1992; 71:27-33. [PubMed: 1606665]

17. Westedt U, Barbu-Tudoran L, Schaper AK, Kalinowski M, Alfke H, Kissel T. Effects of different application parameters on penetration characteristics and arterial vessel wall integrity after local nanoparticle delivery using a porous balloon catheter. European Journal of Pharmaceutics and Biopharmaceutics. 2004; 58:161-168. [PubMed: 15207550]

18. Karanian JW, Peregoy JA, Chiesa OA, Murray TL, Ahn C, Pritchard WF. Efficiency of drug delivery to the coronary arteries in swine is dependent on the route of administration: Assessment of luminal, intimal, and adventitial coronary artery and venous delivery methods. Journal of Vascular and Interventional Radiology. 2010; 21:1555-1564. [PubMed: 20813544]

19. Tepe G, Duda SH, Kalinowski M, Kamenz J, Brehme U, Hanke H, Claussen CD, Bares R, Baumbach A, Dinkelborg LM. Local intra-arterial drug delivery for prevention of restenosis: Comparison of the efficiency of delivery of different radiopharmaceuticals through a porous catheter. Investigative Radiology. 2001; 36:245-249. [PubMed: 11323511]

20. Westedt U, Barbu-Tudoran L, Schaper A, Kalinowski M, Alfke H, Kissel T. Deposition of nanoparticles in the arterial vessel by porous balloon catheters: Localization by confocal laser scanning microscopy and transmission electron microscopy. The AAPS Journal. 2002; 4:206-211.

21. Plante S, Dupuis G, Mongeau CJ, Durand P. Porous balloon catheters for local delivery: Assessment of vascular damage in a rabbit iliac angioplasty model. Journal of the American College of Cardiology. 1994; 24:820-824. [PubMed: 8077558]

22. Lambert C, Leone J, Rowland S. Local drug delivery catheters: Functional comparison of porous and microporous designs. Coronary Artery Disease. 1993; 4:469-475. [PubMed: 8261224]

23. Kipshidze N, Iversen P, Overlie P, Dunlap T, Titus B, Lee D, Moses J, O'Hanley P, Lauer M, Leon MB. First human experience with local delivery of novel antisense avi-4126 with infiltrator catheter in de novo native and restenotic coronary arteries: 6-month clinical and angiographic follow-up from avail study. Cardiovascular Revascularization Medicine. 2007; 8:230-235. [PubMed: 18053943]

24. Nasser TK, Wilensky RL, Mehdi K, March KL. Microparticle deposition in periarterial microvasculature and intramural dissections after porous balloon delivery into atherosclerotic vessels: Quantitation and localization by confocal scanning laser microscopy. American Heart Journal. 1996; 131:892-898. [PubMed: 8615307]

25. Wilensky R, March KL, Gradus-Pizlo I, Schwauwecker D, Michaels M, Robinson J, Carlson K, Hathaway DR. Regional and arterial localization of radioactive microparticles after local delivery by unsupported or supported porous balloon catheters. American Heart Journal. 1995; 129:852859. [PubMed: 7732972] 
26. Scheller B, Hehrlein C, Bocksch W, Rutsch W, Haghi D, Dietz U, Bohm M, Speck U. Treatment of coronary in-stent restenosis with a paclitaxel-coated balloon catheter. N Engl J Med. 2006; 355:2113-2124. [PubMed: 17101615]

27. Unverdorben M, Vallbracht C, Cremers B, Heuer H, Hengstenberg C, Maikowski C, Werner GS, Antoni D, Kleber FX, Bocksch W, Leschke M, Ackermann H, Boxberger M, Speck U, Degenhardt R, Scheller B. Paclitaxel-coated balloon catheter versus paclitaxel-coated stent for the treatment of coronary in-stent restenosis. Circulation. 2009; 119:2986-2994. [PubMed: 19487593]

28. Cortese B, Micheli A, Picchi A, Coppolaro A, Bandinelli L, Severi S, Limbruno U. Paclitaxelcoated balloon versus drug-eluting stent during pci of small coronary vessels, a prospective randomised clinical trial. The piccoleto study. Heart. 2010; 96:1291-1296. [PubMed: 20659948]

29. Oberhoff M, Herdeg C, Al Ghobainy R, Cetin S, Küttner A, Horch B, Baumbach A, Karsch KR. Local delivery of paclitaxel using the double-balloon perfusion catheter before stenting in the porcine coronary artery. Catheterization and Cardiovascular Interventions. 2001; 53:562-568. [PubMed: 11515014]

30. Dommke C, Haase KK, Sueselbeck T, Streitner I, Haghi D, Metz J, Borggrefe M, Herdeg C. Local paclitaxel delivery after coronary stenting in an experimental animal model. Thrombosis and Haemostasis. 2007; 98:674-680. [PubMed: 17849059]

31. Nef H, Möllmann H, Joseph A, Troidl C, Voss S, Rauch M, Kinscherf R, Vogt A, Weber M, Hamm C, Elsässer A. Reduction of neointimal hyperplasia in porcine coronary arteries by 2deoxy-d-glucose. Clinical Research in Cardiology. 2009; 98:355-361. [PubMed: 19543785]

32. Nabel EG, Plautz G, Nabel GJ. Site-specific gene expression in vivo by direct gene transfer into the arterial wall. Science. 1990; 249:1285-1288. [PubMed: 2119055]

33. Garg S, Serruys PW. Coronary stents: Current status. Journal of the American College of Cardiology. 2010; 56:S1-S42. [PubMed: 20797502]

34. Togni M, Windecker S, Cocchia R, Wenaweser P, Cook S, Billinger M, Meier B, Hess OM. Sirolimus-eluting stents associated with paradoxic coronary vasoconstriction. Journal of the American College of Cardiology. 2005; 46:231-236. [PubMed: 16022947]

35. Hofma SH, van der Giessen WJ, van Dalen BM, Lemos PA, McFadden EP, Sianos G, Ligthart JMR, van Essen D, de Feyter PJ, Serruys PW. Indication of long-term endothelial dysfunction after sirolimus-eluting stent implantation. European Heart Journal. 2006; 27:166-170. [PubMed: 16249221]

36. Hwang C-W, Wu D, Edelman ER. Physiological transport forces govern drug distribution for stent-based delivery. Circulation. 2001; 104:600-605. [PubMed: 11479260]

37. Ong A, T L, McFadden EP, Regar E, de Jaegere PPT, van Domburg RT, Serruys PW. Late angiographic stent thrombosis (last) events with drug-eluting stents. Journal of the American College of Cardiology. 2005; 45:2088-2092. [PubMed: 15963413]

38. Iakovou I, Schmidt T, Bonizzoni E, Ge L, Sangiorgi GM, Stankovic G, Airoldi F, Chieffo A, Montorfano M, Carlino M, Michev I, Corvaja N, Briguori C, Gerckens U, Grube E, Colombo A. Incidence, predictors, and outcome of thrombosis after successful implantation of drug-eluting stents. JAMA. 2005; 293:2126-2130. [PubMed: 15870416]

39. Collet J-P, Aout M, Alantar A, Coriat P, Napoléon B, Thomas D, Trosini-Desert V, Tucas G, Vicaut É, Montalescot G. Real-life management of dual antiplatelet therapy interruption: The regina survey. Archives of Cardiovascular Diseases. 2009; 102:697-710. [PubMed: 19913771]

40. Iakovou I, Schmidt T, Bonizzoni E, Ge L, Sangiorgi GM, Stankovic G, Airoldi F, Chieffo A, Montorfano M, Carlino M, Michev I, Corvaja N, Briguori C, Gerckens U, Grube E, Colombo A. Incidence, predictors, and outcome of thrombosis after successful implantation of drug-eluting stents. JAMA: The Journal of the American Medical Association. 2005; 293:2126-2130. [PubMed: 15870416]

41. Grines CL, Bonow RO, Casey DE Jr, Gardner TJ, Lockhart PB, Moliterno DJ, O'Gara P, Whitlow P. Prevention of premature discontinuation of dual antiplatelet therapy in patients with coronary artery stents: A science advisory from the american heart association, american college of cardiology, society for cardiovascular angiography and interventions, american college of surgeons, and american dental association, with representation from the american college of physicians. Circulation. 2007; 115:813-818. [PubMed: 17224480] 
42. Grube E, Lansky A, Hauptmann KE, Di Mario C, Di Sciascio G, Colombo A, Silber S, Stumpf J, Reifart N, Fajadet J, Marzocchi A, Schofer J, Dumas P, Hoffmann R, Guagliumi G, Pitney M, Russell ME. High-dose 7-hexanoyltaxol-eluting stent with polymer sleeves for coronary revascularization: One-year results from the score randomized trial. Journal of the American College of Cardiology. 2004; 44:1368-1372. [PubMed: 15464315]

43. Malik N, Gunn J, Shepherd L, Crossman DC, Cumberland DC, Holt CM. Phosphorylcholinecoated stents in porcine coronary arteries: In vivo assessment of biocompatibility. Journal of Invasive Cardiology. 2001; 13:193-201. [PubMed: 11231644]

44. Kuiper KKJ, Robinson KA, Chronos NAF, Cui J, Palmer SJ, Nordrehaug JE. Phosphorylcholinecoated metallic stents in rabbit iliac and porcine coronary arteries. Scandinavian Cardiovascular Journal. 1998; 32:261-268. [PubMed: 9834999]

45. Van der Giessen WJ, Lincoff AM, Schwartz RS, Van Beusekom HMM, Serruys PW, Holmes DR Jr, Ellis SG, Topol EJ. Marked inflammatory sequelae to implantation of biodegradable and nonbiodegradable polymers in porcine coronary arteries. Circulation. 1996; 94:1690-1697. [PubMed: 8840862]

46. Garg S, Serruys PW. Coronary stents: Looking forward. Journal of the American College of Cardiology. 2010; 56:S43-S78. [PubMed: 20797503]

47. John MC, Wessely R, Kastrati A, Schomig A, Joner M, Uchihashi M, Crimins J, Lajoie S, Kolodgie FD, Gold HK, Virmani R, Finn AV. Differential healing responses in polymer- and nonpolymer-based sirolimus-eluting stents. JACC: Cardiovascular Interventions. 2008; 1:535-544. [PubMed: 19463356]

48. Nakazawa G, Finn AV, John MC, Kolodgie FD, Virmani R. The significance of preclinical evaluation of sirolimus-, paclitaxel-, and zotarolimus-eluting stents. The American Journal of Cardiology. 2007; 100:S36-S44.

49. Schachinger V, Britten MB, Zeiher AM. Prognostic impact of coronary vasodilator dysfunction on adverse long-term outcome of coronary heart disease. Circulation. 2000; 101:1899-1906. [PubMed: 10779454]

50. Suwaidi JA, Hamasaki S, Higano ST, Nishimura RA, Holmes DR Jr, Lerman A. Long-term follow-up of patients with mild coronary artery disease and endothelial dysfunction. Circulation. 2000; 101:948-954. [PubMed: 10704159]

51. Targonski PV, Bonetti PO, Pumper GM, Higano ST, Holmes DR Jr, Lerman A. Coronary endothelial dysfunction is associated with an increased risk of cerebrovascular events. Circulation. 2003; 107:2805-2809. [PubMed: 12771004]

52. Lincoff AM, Furst JG, Ellis SG, Tuch RJ, Topol EJ. Sustained local delivery of dexamethasone by a novel intravascular eluting stent to prevent restenosis in the porcine coronary injury model. Journal of the American College of Cardiology. 1997; 29:808-816. [PubMed: 9091528]

53. Mehran R, Nikolsky E, Camenzind E, Zelizko M, Kranjec I, Seabra-Gomes R, Negoita M, Slack S, Lotan C. An internet-based registry examining the efficacy of heparin coating in patients undergoing coronary stent implantation. American Heart Journal. 2005; 150:1171-1176. [PubMed: 16338254]

54. Aggarwal RK, Ireland DC, Azrin MA, Ezekowitz MD, De Bono DP, Gershlick AH. Antithrombotic potential of polymer-coated stents eluting platelet glycoprotein iib/iiia receptor antibody. Circulation. 1996; 94:3311-3317. [PubMed: 8989145]

55. Serruys PW, Ormiston JA, Sianos G, Sousa JE, Grube E, den Heijer P, de Feyter P, Buszman P, Schömig A, Marco J, Polonski L, Thuesen L, Zeiher AM, Bett JHN, Suttorp MJ, Glogar HD, Pitney M, Wilkins GT, Whitbourn R, Veldhof S, Miquel K, Johnson R, Coleman L, Virmani R. Actinomycin-eluting stent for coronary revascularization: A randomized feasibility and safety study: The action trial. Journal of the American College of Cardiology. 2004; 44:1363-1367. [PubMed: 15464314]

56. Suzuki T, Kopia G, Hayashi SI, Bailey LR, Llanos G, Wilensky R, Klugherz BD, Papandreou G, Narayan P, Leon MB, Yeung AC, Tio F, Tsao PS, Falotico R, Carter AJ. Stent-based delivery of sirolimus reduces neointimal formation in a porcine coronary model. Circulation. 2001; 104:11881193. [PubMed: 11535578]

57. Klugherz BD, Llanos G, Lieuallen W, Kopia GA, Papandreou G, Narayan P, Sasseen B, Adelman SJ, Falotico R, Wilensky RL, Sobel BE, Maseri A, Yacoub M. Twenty-eight-day efficacy and 
phamacokinetics of the sirolimus-eluting stent. Coronary Artery Disease. 2002; 13:183-188. [PubMed: 12131023]

58. Carter AJ, Aggarwal M, Kopia GA, Tio F, Tsao PS, Kolata R, Yeung AC, Llanos G, Dooley J, Falotico R. Long-term effects of polymer-based, slow-release, sirolimus-eluting stents in a porcine coronary model. Cardiovascular Research. 2004; 63:617-624. [PubMed: 15306217]

59. Degertekin M, Serruys PW, Foley DP, Tanabe K, Regar E, Vos J, Smits PC, van der Giessen WJ, van den Brand M, de Feyter P, Popma JJ. Persistent inhibition of neointimal hyperplasia after sirolimus-eluting stent implantation: Long-term (up to 2 years) clinical, angiographic, and intravascular ultrasound follow-up. Circulation. 2002; 106:1610-1613. [PubMed: 12270850]

60. Fajadet J, Morice M-C, Bode C, Barragan P, Serruys PW, Wijns W, Constantini CR, Guermonprez J-L, Eltchaninoff H, Blanchard D, Bartorelli A, Laarman G-J, Perin M, Sousa JE, Schuler G, Molnar F, Guagliumi G, Colombo A, Ban Hayashi E, Wulfert E. Maintenance of long-term clinical benefit with sirolimus-eluting coronary stents: Three-year results of the ravel trial. Circulation. 2005; 111:1040-1044. [PubMed: 15723977]

61. van Beusekom HMM, Saia F, Zindler JD, Lemos PA, Hoor SLS-t, van Leeuwen MAH, de Feijter PJ, Serruys PW, van der Giessen WJ. Drug-eluting stents show delayed healing: Paclitaxel more pronounced than sirolimus. European Heart Journal. 2007; 28:974-979. [PubMed: 17434882]

62. Langeveld B, van Gilst WH, Tio RA, Zijlstra F, Roks AJM. Angiotensin-(1-7) attenuates neointimal formation after stent implantation in the rat. Hypertension. 2005; 45:138-141. [PubMed: 15545510]

63. Walter DH, Cejna M, Diaz-Sandoval L, Willis S, Kirkwood L, Stratford PW, Tietz AB, Kirchmair R, Silver M, Curry C, Wecker A, Yoon YS, Heidenreich R, Hanley A, Kearney M, Tio FO, Kuenzler P, Isner JM, Losordo DW. Local gene transfer of phvegf-2 plasmid by gene-eluting stents: An alternative strategy for inhibition of restenosis. Circulation. 2004; 110:36-45. [PubMed: 15210598]

64. Weiwei Z, Guangqing C, Yanwei X, Na Z. New approach for local delivery of rapamycin by bioadhesive plga-carbopol nanoparticles. Drug Delivery. 2009; 16:15-23. [PubMed: 19555304]

65. Chorny M, Fishbein I, Yellen BB, Alferiev IS, Bakay M, Ganta S, Adamo R, Amiji M, Friedman G, Levy RJ. Targeting stents with local delivery of paclitaxel-loaded magnetic nanoparticles using uniform fields. Proceedings of the National Academy of Sciences of the United States of America. 2010; 107:8346-8351. [PubMed: 20404175]

66. Almenar-Queralt A, Duperray A, Miles LA, Felez J, Altieri DC. Apical topography and modulation of icam-1 expression on activated endothelium. American Journal of Pathology. 1995; 147:1278-1288. [PubMed: 7485391]

67. Dustin M, Rothlein R, Bhan A, Dinarello C, Springer T. Induction by il 1 and interferon-gamma: Tissue distribution, biochemistry, and function of a natural adherence molecule (icam-1). The Journal of Immunology. 1986; 137:245-254. [PubMed: 3086451]

68. Panes J, Perry MA, Anderson DC, Manning A, Leone B, Cepinskas G, Rosenbloom CL, Miyasaka M, Kvietys PR, Granger DN. Regional differences in constitutive and induced icam-1 expression in vivo. American Journal of Physiology - Heart and Circulatory Physiology. 1995; 269:H1955H1964.

69. DeMeester SR, Molinari MA, Shiraishi T, Okabayashi K, Manchester JK, Wick MR, Cooper JD, Patterson GA. Attenuation of rat lung isograft reperfusion injury with a combination of antiicam-1 and anti-beta2 integrin monoclonal antibodies. Transplantation. 1996; 62:1477-1485. [PubMed: 8958275]

70. Muro S, Wiewrodt R, Thomas A, Koniaris L, Albelda SM, Muzykantov VR, Koval M. A novel endocytic pathway induced by clustering endothelial icam-1 or pecam-1. J Cell Sci. 2003; 116:1599-1609. [PubMed: 12640043]

71. Muro S, Cui X, Gajewski C, Murciano J-C, Muzykantov VR, Koval M. Slow intracellular trafficking of catalase nanoparticles targeted to icam-1 protects endothelial cells from oxidative stress. American Journal of Physiology - Cell Physiology. 2003; 285:C1339-C1347. [PubMed: 12878488]

72. Muro S, Gajewski C, Koval M, Muzykantov VR. Icam-1 recycling in endothelial cells: A novel pathway for sustained intracellular delivery and prolonged effects of drugs. Blood. 2005; 105:650658. [PubMed: 15367437] 
73. Zhang N, Chittasupho C, Duangrat C, Siahaan TJ, Berkland C. Plga nanoparticle-peptide conjugate effectively targets intercellular cell-adhesion molecule-1. Bioconjugate Chemistry. 2007; 19:145-152. [PubMed: 17997512]

74. Danila D, Partha R, Elrod DB, Lackey M, Casscells SW, Conyers JL. Antibody-labeled liposomes for ct imaging of atherosclerotic plaques. Texas Heart Institute Journal. 2009; 36:393-403. [PubMed: 19876414]

75. Nahrendorf M, Jaffer FA, Kelly KA, Sosnovik DE, Aikawa E, Libby P, Weissleder R. Noninvasive vascular cell adhesion molecule-1 imaging identifies inflammatory activation of cells in atherosclerosis. Circulation. 2006; 114:1504-1511. [PubMed: 17000904]

76. Garnacho C, Albelda SM, Muzykantov VR, Muro S. Differential intra-endothelial delivery of polymer nanocarriers targeted to distinct pecam-1 epitopes. Journal of Controlled Release. 2008; 130:226-233. [PubMed: 18606202]

77. Banquy X, Leclair Gg, Rabanel J-M, Argaw A, Bouchard J-Fo, Hildgen P, Giasson S. Selectins ligand decorated drug carriers for activated endothelial cell targeting. Bioconjugate Chemistry. 2008; 19:2030-2039. [PubMed: 18803413]

78. Theoharis S, Krueger U, Tan PH, Haskard DO, Weber M, George AJT. Targeting gene delivery to activated vascular endothelium using anti e/p-selectin antibody linked to pamam dendrimers. Journal of Immunological Methods. 2009; 343:79-90. [PubMed: 19186182]

79. Muro S, Garnacho C, Champion JA, Leferovich J, Gajewski C, Schuchman EH, Mitragotri S, Muzykantov VR. Control of endothelial targeting and intracellular delivery of therapeutic enzymes by modulating the size and shape of icam-1-targeted carriers. Mol Ther. 2008; 16:1450-1458. [PubMed: 18560419]

80. Calderon AJ, Bhowmick T, Leferovich J, Burman B, Pichette B, Muzykantov V, Eckmann DM, Muro S. Optimizing endothelial targeting by modulating the antibody density and particle concentration of anti-icam coated carriers. Journal of Controlled Release. 2011; 150:37-44. [PubMed: 21047540]

81. Arap W, Kolonin MG, Trepel M, Lahdenranta J, Cardo-Vila M, Giordano RJ, Mintz PJ, Ardelt PU, Yao VJ, Vidal CI, Chen L, Flamm A, Valtanen H, Weavind LM, Hicks ME, Pollock RE, Botz GH, Bucana CD, Koivunen E, Cahill D, Troncoso P, Baggerly KA, Pentz RD, Do K-A, Logothetis CJ, Pasqualini R. Steps toward mapping the human vasculature by phage display. Nat Med. 2002; 8:121-127. [PubMed: 11821895]

82. Pasqualini R, Ruoslahti E. Organ targeting in vivo using phage display peptide libraries. Nature. 1996; 380:364-366. [PubMed: 8598934]

83. Hajitou A, Trepel M, Lilley CE, Soghomonyan S, Alauddin MM, Marini Iii FC, Restel BH, Ozawa MG, Moya CA, Rangel R, Sun Y, Zaoui K, Schmidt M, von Kalle C, Weitzman MD, Gelovani JG, Pasqualini R, Arap W. A hybrid vector for ligand-directed tumor targeting and molecular imaging. Cell. 2006; 125:385-398. [PubMed: 16630824]

84. Li Y, Yu J, Wang Y, Griffin NM, Long F, Shore S, Oh P, Schnitzer JE. Enhancing identifications of lipid-embedded proteins by mass spectrometry for improved mapping of endothelial plasma membranes in vivo. Molecular \& Cellular Proteomics. 2009; 8:1219-1235. [PubMed: 19155209]

85. Mah C, Fraites JTJ, Zolotukhin I, Song S, Flotte TR, Dobson J, Batich C, Byrne BJ. Improved method of recombinant aav2 delivery for systemic targeted gene therapy. Mol Ther. 2002; 6:106112. [PubMed: 12095310]

86. Scherer F, Anton M, Schillinger U, Henke J, Bergemann C, Krueger A, Gaensbacher B, Plank C. Magnetofection: Enhancing and targeting gene delivery by magnetic force in vitro and in vivo. Gene Therapy. 2009; 9:102-109. [PubMed: 11857068]

87. Namgung R, Singha K, Yu MK, Jon S, Kim YS, Ahn Y, Park I-K, Kim WJ. Hybrid superparamagnetic iron oxide nanoparticle-branched polyethylenimine magnetoplexes for gene transfection of vascular endothelial cells. Biomaterials. 2010; 31:4204-4213. [PubMed: 20170956]

88. Chorny M, Hood E, Levy RJ, Muzykantov VR. Endothelial delivery of antioxidant enzymes loaded into non-polymeric magnetic nanoparticles. Journal of Controlled Release. 2010; 146:144151. [PubMed: 20483366] 
89. Frias JC, Williams KJ, Fisher EA, Fayad ZA. Recombinant hdl-like nanoparticles: A specific contrast agent for mri of atherosclerotic plaques. J. Am. Chem. Soc. 2004; 126:16316-16317. [PubMed: 15600321]

90. Frias JC, Ma Y, Williams KJ, Fayad ZA, Fisher EA. Properties of a versatile nanoparticle platform contrast agent to image and characterize atherosclerotic plaques by magnetic resonance imaging. Nano Lett. 2006; 6:2220-2224. [PubMed: 17034087]

91. Cormode DP, Briley-Saebo KC, Mulder WJM, Aguinaldo JGS, Barazza A, Ma Y, Fisher EA, Fayad ZA. An apoa-i mimetic peptide high-density-lipoprotein-based mri contrast agent for atherosclerotic plaque composition detection. Small. 2008; 4:1437-1444. [PubMed: 18712752]

92. Cormode DP, Skajaa T, van Schooneveld MM, Koole R, Jarzyna P, Lobatto ME, Calcagno C, Barazza A, Gordon RE, Zanzonico P, Fisher EA, Fayad ZA, Mulder WJM. Nanocrystal core highdensity lipoproteins: A multimodality contrast agent platform. Nano Letters. 2008; 8:3715-3723. [PubMed: 18939808]

93. Feng M, Cai Q, Huang H, Zhou P. Liver targeting and anti-hbv activity of reconstituted hdlacyclovir palmitate complex. European Journal of Pharmaceutics and Biopharmaceutics. 2008; 68:688-693. [PubMed: 17890068]

94. Virmani R, Burke AP, Kolodgie FD, Farb A. Vulnerable plaque: The pathology of unstable coronary lesions. Journal of Interventional Cardiology. 2002; 15:439-446. [PubMed: 12476646]

95. Hyafil F, Cornily J-C, Feig JE, Gordon R, Vucic E, Amirbekian V, Fisher EA, Fuster V, Feldman LJ, Fayad ZA. Noninvasive detection of macrophages using a nanoparticulate contrast agent for computed tomography. Nat Med. 2007; 13:636-641. [PubMed: 17417649]

96. Amirbekian V, Lipinski MJ, Briley-Saebo KC, Amirbekian S, Aguinaldo JGS, Weinreb DB, Vucic E, Frias JC, Hyafil F, Mani V, Fisher EA, Fayad ZA. Detecting and assessing macrophages in vivo to evaluate atherosclerosis noninvasively using molecular mri. PNAS. 2007; 104:961-966. [PubMed: 17215360]

97. Cyrus T, Winter PM, Caruthers SD, Wickline SA, Lanza GM. Magnetic resonance nanoparticles for cardiovascular molecular imaging and therapy. Expert Review of Cardiovascular Therapy. 2005; 3:705-715. [PubMed: 16076280]

98. Cyrus T, Abendschein DR, Caruthers SD, Harris TD, Glattauer V, Werkmeister JA, Ramshaw JAM, Wickline SA, Lanza GM. Mr three-dimensional molecular imaging of intramural biomarkers with targeted nanoparticles. Journal of Cardiovascular Magnetic Resonance. 2006; 8:535-541. [PubMed: 16755843]

99. Cyrus T, Zhang H, Allen JS, Williams TA, Hu G, Caruthers SD, Wickline SA, Lanza GM. Intramural delivery of rapamycin with $\{$ alpha $\} \vee$ \{beta $\}$-targeted paramagnetic nanoparticles inhibits stenosis after balloon injury. Arterioscler Thromb Vasc Biol. 2008 ATVBAHA. 107.156281.

100. Lanza GM, Winter PM, Caruthers SD, Hughes MS, Cyrus T, Marsh JN, Neubauer AM, Partlow KC, Wickline SA. Nanomedicine opportunities for cardiovascular disease with perfluorocarbon nanoparticles. Nanomedicine. 2006; 1:321-329. [PubMed: 17716162]

101. Wang X-F, Jin P-P, Tong Zhou, Zhao Y-P, Ding Q-L, Wang D-B, Zhao G-M, Jing-Dai, Wang HL, Ge H-L. Mr molecular imaging of thrombus: Development and application of a gd-based novel contrast agent targeting to p-selectin. Clinical and Applied Thrombosis/Hemostasis. 2010; 16:177-183. [PubMed: 19141485]

102. Srinivasan R, Marchant RE, Gupta AS. In vitro and in vivo platelet targeting by cyclic rgdmodified liposomes. Journal of Biomedical Materials Research Part A. 2010; 93A:1004-1015. [PubMed: 19743511]

103. Lanza GM, Wallace KD, Scott MJ, Cacheris WP, Abendschein DR, Christy DH, Sharkey AM, Miller JG, Gaffney PJ, Wickline SA. A novel site-targeted ultrasonic contrast agent with broad biomedical application. Circulation. 1996; 94:3334-3340. [PubMed: 8989148]

104. Pan D, Senpan A, Caruthers SD, Williams TA, Scott MJ, Gaffney PJ, Wickline SA, Lanza GM. Sensitive and efficient detection of thrombus with fibrin-specific manganese nanocolloids. Chemical Communications. 2009:3234-3236. [PubMed: 19587924] 


\begin{tabular}{|l|c|c|}
\hline & Non-targeted delivery & Targeted delivery \\
\hline Targeting specific epitopes & - & + \\
\hline Targeting specific cells & - & + \\
\hline Ex vivo labeling of cells & + & + \\
\hline Enhancement of delivery through utilization of a magnetic field (magnetofection) & + & + \\
\hline Delivery in conjunction with an interventional procedure & + & + \\
\hline Systemic delivery without an interventional procedure & - & --+ \\
\hline Prolonged local contact necessary for delivery & +++ & --+ \\
\hline Downstream effects, i.e. washout of nanoparticles & ++-+++ & --+ \\
\hline
\end{tabular}


Table 2

Targets for nanoparticle-facilitated vascular imaging and therapy

\begin{tabular}{|l|l|l|}
\hline \multirow{2}{*}{ Target cell or tissue } & Target epitope or technology & References \\
\hline \multirow{5}{*}{ Endothelial cells } & ICAM-1 & $71-74,80$ \\
\cline { 2 - 3 } & VCAM-1 & 75 \\
\cline { 2 - 3 } & PECAM-1 & 76 \\
\cline { 2 - 3 } & E-, P-selectin & 77,78 \\
\cline { 2 - 3 } & Superparamagnetic nanoparticles & 87 \\
\hline \multirow{5}{*}{ Macrophages and lipid-containing atheroma in the vascular wall } & Spherical, reconstituted (r) HDL particles & 89 \\
\cline { 2 - 3 } & Disk-shaped HDL-like particles & 90 \\
\cline { 2 - 3 } & Fully synthetic nanoparticles & $92,95,96$ \\
\hline \multirow{5}{*}{ Smooth muscle cells in the media } & Magnetic nanoparticles & $65,98,99$ \\
\cline { 2 - 3 } & a $\beta_{3}$-integrin & 98,99 \\
\hline \multirow{2}{*}{ Thrombus imaging } & P-selectin & 101 \\
\cline { 2 - 3 } & GpIlb/IIIa integrin & 102 \\
\cline { 2 - 3 } & Fibrin & 104 \\
\hline \multirow{5}{*}{ Novel epitopes on various cells } & $\begin{array}{l}\text { Phage-display or proteomics-based technologies to screen } \\
\text { for novel targets }\end{array}$ & $81,83,84$ \\
\hline
\end{tabular}

